\title{
EXAMINATIONS ON THE PROTECTIVE IMMUNITY TO THE COMMON LIVER FLUKE, FASCIOLA IN RATS, USING IMMUNOSUPPRESSANTS OR DIFFUSION CHAMBER TECHNIQUES
}

\author{
Yoshinisa Hashiguchi \\ Received for publication 16 February 1981
}

\begin{abstract}
The current study was designed to obtain an information on the immune factors which could be underlying the induction of protective immunity to the genus Fasciola in rats, using immunosuppressive drugs and diffusion chamber technique. The rats became resistant to challenge with the Japanese species of Fasciola following an oral infection with metacercariae, indicating a significant degree of reduced worm burdens. This protective effect in the immunized rats, however, was abrogated by the administration of immunosuppressants, dexamethasone and prednisolone. In rats treated with these drugs, no antigen-antibody band in immunodiffusion plate was recognized throughout the infection, while many bands were observed in sera from the rats without treatment with the drugs. From the results obtained, the antigen-antibody bands in diffusion plate would be a good indicator to estimate the degree of protective immunity to the genus Fasciola in host animals. By intraperitoneally implanting the immature worms in diffusion chamber, the rats were able to induce a significantly high degree of protective immunity when compared to the natural-immunity control. However, the degree of protective effect was significantly high in rats which received free worm (without chamber) implantation. In the experimental rats, each fraction of their serum proteins was also examined by performing cellulose acetate electrophoresis. More detailed examination is required to investigate the immune factors in the protective immunity to the fluke in rats, using immunosuppressive drugs and/or diffusion chamber techniques in terms of host-parasite relationship.
\end{abstract}

\section{INTRODUCTION}

The Japanese common liver fluke, Fasciola sp. indicates a similarity to $F$. hepatica and $F$. gigantica in the migration and development in the final hosts (Ono and Isoda, 1952; Mimura, 1961), though its taxonomical status has not yet been established (Watanabe, 1965). So far as is known, little immunological study on the hosts infected with the Japanese Fasciola species has been carried out in terms of the protective immunity to the fluke. The protective immunity of rats against $F$. hepatica, on the other hand, has been widely recognized (Hayes et al., 1972; Goose and MacGregor, 1973; Armour and Dargie, 1974; Rajasekariah and Howell, 1977, 1978). This immunity is induced not only by the oral infection of the normal or irradiated metacercariae but also by the implantation of the different ages of the liver fluke in

Department of Parasitology, Kochi Medical School, Nankoku City 781-51, Kochi, Japan. 
rats (Thorpe and Broome, 1962; Eriksen and Flagstad, 1974; Anderson et al., 1975; Rajasekariah and Howell, 1978). Moreover, the resistance of rats to reinfection with $F$. hepatica is also stimulated by the transfer to naive animals with the serum or lymphoid cells from infected ones (Corba et al., 1971; Armour and Dargie, 1974; Hayes et al., 1974a, b; Dargie et al., 1974; Howell et al., 1977; Rajasekariah and Howell, 1979). Thus, so far, the previous works have provided much important information on the immunological factors involved. The factors, however, should still be clarified to have a better understanding of the mechanisms which could be underlying the induction of protective immunity to Fasciola in host animals.

In the immunizing infection with the subcutaneous implantation of immature worms, 4 week-old, Rajasekariah and Howell (1978) have observed a significant degree of resistance to $F$. hopatica in rats. According to Lang et al. (1972), moreover, the immunization with different ages ( 8 and 16 day-old) of worms produced a significant reduction in challenge worm burdens when compared to natural immunity (challenge) controls in mice. By subcutaneously implanting adult worms, on the other hand, Eriksen and Flagstad (1974) and Anderson et al. (1975) also showed some degree of protective immunity to challenge infection in rats, although Rajasekariah and Howell (1978) could not recognize any protection following subcutaneous implantation with the adults. In this immunity, but, the duration of liver migration by young worms may be of greater importance in stimulating the protective immunity than is worm age (Lang, 1974). From these facts, anyway, there may be several factors to induce protective immunity in relation to the age or liver migration of immunizing worms in the host.

In the series of experiments reported hitherto, the observation seems to indicate a complexity of the protective immune factors involved. The present study, therefore, attempts to stimulate the hosts (rats) by introducing living parasite contained in a millipore diffusion chamber. In this method, a variety of soluble antigens would become effective, but the inability of the liver fluke to infect the host would reduce or eliminate all of the pathology usually associated with the infection, without liver and/or bile duct migration of the worms. In addition, the current work is designed to determine the effects of immunosuppressants on the induction of protective immunity to the Japanese common liver fluke in rats.

\section{Materials AND Methods}

Animals. Male, around $250 \mathrm{~g}$ Wistar rats were used throughout the experiments. They were fed a commercially prepared diet and received water ad libitum.

Parasites. All the Japanese species of the genus Fasciola metacercariae were from the same batach. They were collected from experimentally infected Austropeplea ollula (Lymnea ollula) and administered per os to rats in normal saline, using an injection syringe with a slender vinyl tube.

Immunosuppressive drugs. Dexamethasone (Merck Decadrone) and prednisolone (Merck Codelcortone) were simultaneously administered into alternate thigh muscles of rats beginning one day before immunizing inoculation of the metacercariae, and continued every five days until necropsy. The dosage levels of these drugs are 
$1 \mathrm{mg} / \mathrm{rat}$ in Decadrone and $5 \mathrm{mg} / \mathrm{rat}$ in Codelcortone.

Preparation and implantation of diffusion chambers into rats. Diffusion chambers (Millipore Filter Corp., Bedford, Massachusetts) were made of diffusion chamber ring (Plexiglass U-100, diameter: $10 \mathrm{~mm}$, thickness: $2 \mathrm{~mm}$ ) and millipore filter (pore size: $14 \mu$ ). They were closed with millipore glue after introducing the flukes in sterile saline; the immature, 25 day-old, worms isolated by peptic digestion from stock-infected rats, were introduced aseptically into the chambers. Rats that were to receive diffusion chambers were anesthetized with ethyl ether during operation. The abdominal area of the rats was washed with $70 \%$ ethyl alcohol and a small incision was made either to the right or left of center. A single chamber including two worms was then placed intraperitoneally into each rat with sterile forceps. The incision was closed with a sterile surgical suture and then the area was washed again with $70 \%$ ethyl alcohol including iodine tincture. It was observed that $100 \%$ of the rats survived in these operations.

Experimental design. The experimental design consisted of three series. In the 1st series of the experiment, the degree of protective immunity to the Japanese species of Fasciola in rats was ascertained by the immunizing infection with the metacercariae per os. In the 2 nd, an attempt to induce the protective immunity was made by intraperitoneally implanting the immature worms contained in diffusion chambers, and then the recipients were challenged with the metacercariae. In the $3 \mathrm{rd}$, it was decided to assess the effects of immunosuppressants on the induction of protective immunity to the liver fluke in the animals infected experimentally. Student's " $t$ " test was used to compare worm burdens between groups. Probability values larger than 0.05 were not considered significant. The standard deviation of the mean was calculated for mean worm burdens.

Autopsy. All rats were killed 2 weeks after challenge infection with the metacercariae, unless otherwise mentioned. In each examination the peritoneal cavity was opened, and the surface of the liver and other visceral organs was inspected for haemorrhages. The peritoneal surface was flushed with normal saline and the washings were examined for free worms under a dissecting microscope. All of the internal organs were removed separately, then washed with normal saline several times to recover free worms. The liver and bile ducts were examined for migrating immature worms and/or mature ones. The liver was minced with scissors in petri dishes. In order to obtain the penetrating worms, the minced liver in saline was incubated at $37 \mathrm{C}$ for $2 \mathrm{hrs}$; the incubation revealed that the liver was free from any worms.

Serum examination. Blood samples were collected weekly intervals by cutting the tail part of rats. All sera were analysed with a cellulose acetate electrophoresis cell (Model SE-2, Toyo Kagaku Sangyo) supplying constant current. Serum samples were placed on a cellulose acetate membrane (Separax: Joko Sangyo Co. Ltd.), and then subjected to $0.8 \mathrm{~mA}$ per $1 \mathrm{~cm}$ membrane for 50 minutes The dried strips of cellulose acetate membranes were scanned in a Densitorol DMU-2 (Toyo Kagaku Sangyo), and the relative percentages of albumin, alpha-, beta- and gamma-globulins were determined.

Double immunodiffusion. Ouchterlony plates were prepared by flooding 5 by 
$11 \mathrm{~cm}$ slides with $9.5 \mathrm{ml}$ of $0.9 \%$ agar. The central well was filled with the Fasciola antigen and the other wells with serum samples of rats from each experiment. The position of precipitin bands was recorded by drawings and photographs.

Worm antigen. Adult worms of the common liver fluke, recovered from the bile ducts of stock-infected rats and stored at $-20 \mathrm{C}$, were added to 10 volumes $(\mathrm{W} / \mathrm{V})$ of phosphate buffer, $\mathrm{pH}$ 7.4. The worms were homogenized for 5 minutes at $4 \mathrm{C}$ and centrifuged for 15 minutes at $3,000 \mathrm{rpm}$. The supernatant was stored at $-20 \mathrm{C}$ as the antigen for the agar double diffusion technique.

\section{RESULTS}

Worm recovery from immunized and non-immunized rats 2 weeks after challenge. At 2 weeks after challenge all experimental rats had worms from immunizing infection in their bile ducts. In this series of the experiment, the immunized rats received challenge infection with the metacercariae 6, 7, 8, 9, 10 and 11 weeks after immunizing (1st) infection. As recognized in Table 1, the experimental rats harbored fewer challenge worms than the natural-immunity control, apart from the rats received challenge 11 weeks after immunization. The challenge (natural-immunity) controls harbored 3.6 worms in mean number, whereas the animals challenged during 6 to 9 weeks after immunizing infection harbored only 0.7 to 1.5 worms. The percentage immunity to the Japanese species of Fasciola in rats was calculated by the following formula, $\overline{\mathrm{C}}-\overline{\mathrm{I}} \times 100$, where $\overline{\mathrm{C}}$ indicates a mean worm recovery of challenge control and $\bar{I}$ shows a mean recovery of worms from challenge infection in immunized rats. The challenge infection from 6 to 9 weeks after immunization, revealed a higher percentage immunity ranging from 58.3 to 80.6 than the natural-immunity control. These differences in worm burden are highly significant (Student's " $t$ " test, $\mathrm{P}<$ 0.001 ), but the challenge at 10 weeks later had trended to indicate a gradual decrease in the degree of protective immunity to the liver fluke in rats. Even in the rats which received both immunizing and challenging infections, there was no difficulty in the

Table 1 Summary of the percentage immunity to the Japanese Fasciola in the rats immunized with 4 metacercariae each per os before challenge infection.

\begin{tabular}{|c|c|c|c|c|c|}
\hline \multirow{2}{*}{$\begin{array}{l}\text { Times (wks) of } \\
\text { challenge after } \\
\text { immunization }\end{array}$} & \multirow{2}{*}{$\begin{array}{l}\text { No. rats } \\
\text { used }\end{array}$} & \multirow{2}{*}{$\begin{array}{l}\text { No. larvae } \\
\text { challenged }\end{array}$} & \multicolumn{2}{|c|}{ No. worms recovered from challenge } & \multirow{2}{*}{$\begin{array}{l}\text { Percentage } \\
\text { immunity* } \\
(\%)\end{array}$} \\
\hline & & & Total & Mean \pm s.d. & \\
\hline 6 & 5 & 25 & 4 & $0.8 \pm 0.40$ & 77.8 \\
\hline 7 & 5 & 25 & 4 & $0.8 \pm 0.75$ & 77.8 \\
\hline 8 & 4 & 20 & 6 & $1.5 \pm 1.12$ & 58.3 \\
\hline 9 & 3 & 15 & 2 & $0.7 \pm 0.47$ & 80.6 \\
\hline 10 & 3 & 15 & 8 & $2.7 \pm 0.47$ & 25.0 \\
\hline 11 & 3 & 15 & 13 & $4.3 \pm 1.25$ & 0.0 \\
\hline Challenge control & 5 & 25 & 18 & $3.6 \pm 0.49$ & - \\
\hline
\end{tabular}

* Percentage immunity was calculated by the formula, $\overline{\mathrm{C}}-\overline{\mathrm{I}} / \overline{\mathrm{C}} \times 100$ (Miller and Smithers, 1980) 
differentiation of the worms between the two infections, because of autopsy at the early phase ( 2 weeks) of challenge infection. Thus, the results mentioned above have demonstrated a significant degree of worm reduction from challenge, by the immunization with the Japanese Fasciola metacercariae per os.

Immunization by intraperitoneally implanting worms with and without diffusion chambers. The induction of protective immunity which was observed by the immunizing infection with the metacercariae per os, was examined using millipore diffusion chambers in relation to the liver migration and/or the ages of worms. The rat immunized by implanting worms was challenged 3 weeks after immunization, and autopsied 4 weeks after challenge. In the free worm implantation (without chambers), the differentiation of worms between the immunizing and challenging infections was performed according to the size of the worms recovered. In Table 2, the protective immunity to the Japanese species of Fasciola in rats is shown by performing implantation of the worms with or without chambers. In the experimental rats, the immunized groups indicated a significant degree of protective immunity by the immunizing infection (implantation) of the immature (25 day-old) worms in both with and without chambers. The percentage immunity obtained by the before mentioned formula, was $50.0 \%$ in the immunization with chambers and $88.2 \%$ in that without chambers, respectively. In the worm burden, again, the immunized rats harbored only 1.7 and 0.4 worms in the corresponding immunizations, whereas the rats in sham operation and challenge control showed the worm recovery of 4.2 and 3.4, respectively. The differences found in worm burdens between the immunized, and the non-immunized (sham) and challenge control are highly significant $(\mathrm{P}<0.001)$, but there is no significant difference between sham operation and challenge control. With implantation of the worms contained in diffusion chambers, the current study demonstrated a significant degree of protective immunity to the Japanese Fasciola species when compared to the natural-immunity control. The degree, however, was significantly higher $(\mathrm{P}<0.001)$ in the immunization with free worm implantation than that with enchambered worm; the implanted worms could

Table 2 Results of the induction of protective immunity by intraperitoneally implanting the immature worms, 25 day-old, with and without diffusion chambers in rats.

\begin{tabular}{|c|c|c|c|c|c|c|c|}
\hline \multirow{2}{*}{ Group } & \multirow{2}{*}{$\begin{array}{c}\text { Times (wks) } \\
\text { of challenge } \\
\text { aft. } \\
\text { implantation }\end{array}$} & \multirow{2}{*}{$\begin{array}{c}\text { Times (wks) } \\
\text { of autopsy } \\
\text { aft. } \\
\text { challenge }\end{array}$} & \multirow{2}{*}{$\begin{array}{l}\text { No. } \\
\text { rats } \\
\text { used }\end{array}$} & \multirow{2}{*}{$\begin{array}{l}\text { No. larvae } \\
\text { challenged }\end{array}$} & \multicolumn{2}{|c|}{$\begin{array}{l}\text { No. worms from } \\
\text { challenge }\end{array}$} & \multirow{2}{*}{$\begin{array}{c}\text { Per- } \\
\text { centage } \\
\text { immunity } \\
(\%)\end{array}$} \\
\hline & & & & & Total & Mean \pm s.d. & \\
\hline \multicolumn{8}{|l|}{ Immunized* } \\
\hline With chamber & 3 & 4 & 7 & 70 & 12 & $1.7 \pm 0.45$ & 50.0 \\
\hline $\begin{array}{l}\text { Without chamber } \\
\text { (free worms) }\end{array}$ & 3 & 4 & 5 & 50 & 2 & $0.4 \pm 0.49$ & 88.2 \\
\hline \multicolumn{8}{|l|}{ Non-immunized } \\
\hline $\begin{array}{l}\text { Sham operation } \\
\text { (chamber only) }\end{array}$ & 3 & 4 & 5 & 50 & 21 & $4.2 \pm 0.75$ & 0.0 \\
\hline Challenge control & - & 4 & 7 & 70 & 24 & $3.4 \pm 0.49$ & - \\
\hline
\end{tabular}

* Viable 3 worms each were implanted intraperitoneally in rats. 
survive 3 to 4 weeks or more in the diffusion chambers placed intraperitoneally in rats.

The results of serological analysis on serum samples from the rats that received worm implantation with and without chambers are shown in Figure 1, using cellulose acetate electrophoresis. In the case, the percentage value of each fraction in serum proteins was also determined in the samples from rats received sham operation, taking the blood 2 weeks after operation. The values obtained were $53.5 \pm 3.45 \%$ in blbumin, $13.9 \pm 1.90 \%$ in alpha-globulin, $6.8 \pm 0.25 \%$ in beta-globulin and $19.5 \pm 0.65 \%$ in gamma-globulin, respectively, and the average of albumin per globulin $(\mathrm{A} / \mathrm{G})$ ratio was $1.2 \pm 0.15$. In comparison with the percentage values in sham operation, the values in both groups showed a remarkably higher or lower value in each fraction, demonstrating a great fluctuation. The weekly changes in the valucs, however, were similar in the serum samples from the two experimental groups. It was noted that the percentage value of albumin indicated an increase

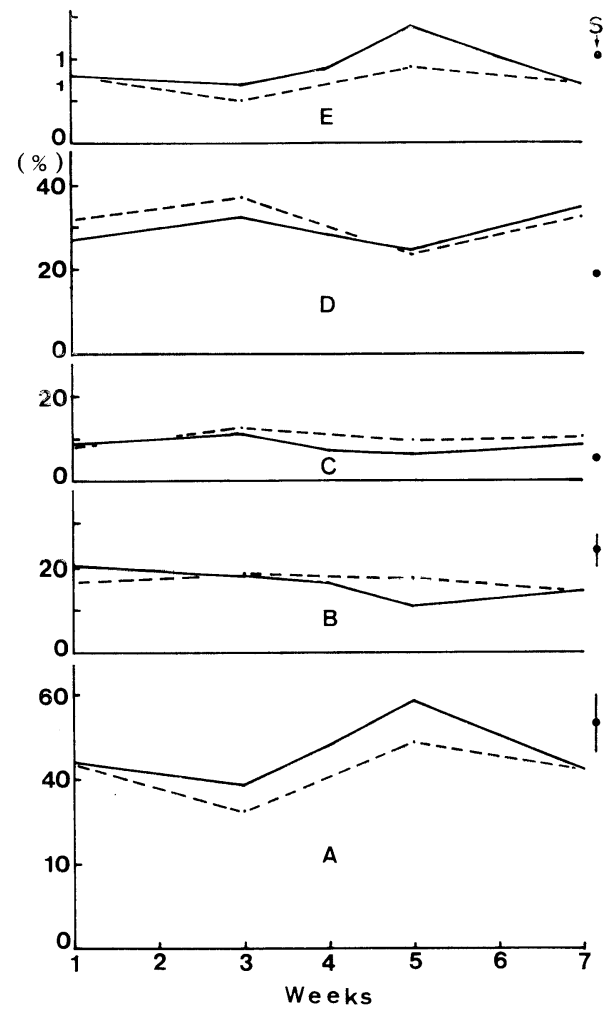

Figure 1 Weekly changes in each fraction of serum proteins in the samples from rats received immunizing implantation of the immature worms with (-) and without (---) chambers. A: albumin, B: alpha-globulin, C: betaglobulin, D: gamma-globulin, $\mathrm{E}: \mathrm{A} / \mathrm{G}$ ratio, $\mathrm{S}$ : mean value of sham operation with empty chamber 2 weeks later. 
after 3 weeks when the rats were challenged, showing the peak at 5 weeks after immunizing infection. In agar double diffusion, almost all of the serum samples showed only one precipitin band in the rats received worm implantation with chambers, while 2 or 3 bands were observed in the samples from the animals implanted worms without chambers (Table 3). It was noted that the number of bands in the latter animals has increased gradually after challenge infection.

Table 3 Number of antigen-antibody bands appeared in agar double diffusion plate in serum samples from rats immunized by intraperitoneally implanting the immature worms with and without diffusion chambers.

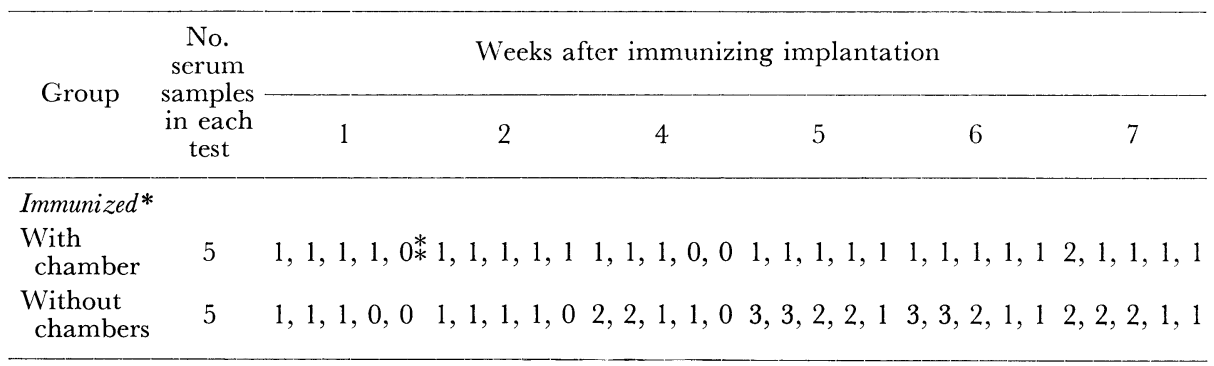

* The rats were challenged with Fasciola metacercariae 3 weeks after immunizing implantation of 25 day-old worms with and without chambers.

** Number of precipitin bands appeared.

Effects of immunosuppressants on the induction of protective immunity. To determine if the protective immunity observed would be influenced by immunosuppressive drugs, the experimental rats which received immunizing infection with the metacercariae per os, were treated with dexamethasone and prednisolone throughout the experiment. The drugs were injected intramuscularly into the animals 5 dayintervals. The rats received the immunizing infection were challenged 6 weeks later with the metacercariae, and then necropsied 2 weeks after the challenge infection. At autopsy all the experimental rats contained worms from immunizing infection in the bile ducts. Table 4 shows the results of this experiment. In the immunizing infection, the non-treated rats (Group II) with immunosuppressive drugs harbored only 0.7 worms, whereas the animals treated (Group I) had 3.3 worms from challenge infection. The percentage immunity of rats in Group II was significantly high $(\mathrm{P}<0.001)$ when compared to both the Group I and natural-immunity control. No significant difference, however, was recognized between Group I and the control. These results demonstrated that the immunosuppressive drugs, dexamethasone and prednisolone, could greatly suppress the induction of protective immunity against the Japanese species of Fasciola in rats. In the immunizing infection (Groups I and II), antigen-antibody systems in the animals were examined by performing Ouchterlony technique. The formation of precipitin bands in agar double diffusion plates is shown in Table 5. Each test was carried out at weekly intervals from 1 to 8 weeks after immunizing infection with the metacercariae. All the serum samples in Group I showed no precipitin band throughout the experiment, while all serum 
samples taken weekly intervals, apart from those 1 week later, in Group II produced 1 to 4 bands. In non-treated animals with immunosuppressive drugs, the bands were first found at 2 weeks and reached to the peak in numbers at 6 weeks when the challenge was performed, thereafter they had a tendency to decrease gradually in numbers. No stimulation was recognized in the activation of antigen-antibody systems in the rats by challenging infection during the period observed.

The results of serological analysis of the samples from rats treated with (Group I) and without (Group II) immunosuppressive drugs are depicted in Figure 2. In the examination of normal (non-infected) rats, the percentages of each fraction were $53.1 \pm 3.79 \%$ in albumin, $18.7 \pm 2.00 \%$ in alpha-globulin, $5.3 \pm 1.62 \%$ in betaglobulin and $18.9 \pm 5.00 \%$ in gamma-globulin, respectively, and the average of albumin per globulin $(\mathrm{A} / \mathrm{G})$ ratio was $1.1 \pm 0.16$. These average normal values are also shown in the same Figure. The gamma-globulin fraction in sera from treated animals (Group I) showed a consistently low percentage, while it represented a high value in the animals without treatment as copared with the average normal value. In other globulin fractions, there was a remarkable difference of alpha-globulin between both groups in the early time of immunizing infection during 1 to 4 weeks;

Table 4 Worm recovery from rats treated with (Group I) and without (Group II) immunosuppressive drugs; all the rats received immunizing infection with 4 metacercariae each per os, and then challenged with 10 or 20 larvae each 6 weeks later.

\begin{tabular}{cccccc}
\hline \multirow{2}{*}{ Group } & No. rats used & $\begin{array}{c}\text { No. larvae } \\
\text { challenged }\end{array}$ & \multicolumn{2}{c}{ No. worms from challenge } & \begin{tabular}{c} 
Percentage \\
immunity \\
\cline { 5 - 6 }
\end{tabular} \\
\cline { 5 - 6 } & 7 & 80 & Total & Mean \pm s.d. & 0.0 \\
\hline II* & 12 & 140 & 8 & $3.3 \pm 0.70$ & 79.3 \\
\hline Challenge control & 17 & 220 & 55 & $3.2 \pm 0.81$ & - \\
\hline
\end{tabular}

* Dexamethasone $(1 \mathrm{mg} / \mathrm{rat})$ and prednisolone $(5 \mathrm{mg} / \mathrm{rat})$ were simultaneously injected into alternate thigh muscles of rats beginning one day before immunizing infection with the metacercariae.

** Non-treated with any immunosuppressive drugs; the rats only received both immunizing and challenging infections with the metacercariae.

Table 5 Number of antigen-antibody bands appeared in agar double diffusion plate in serum samples from rats in each group treated with (Group I) and without (Group II) immunosuppressive drugs.

\begin{tabular}{cccccccccc}
\hline \multirow{2}{*}{ Group } & $\begin{array}{c}\text { No. serum } \\
\text { sampler in } \\
\text { each test }\end{array}$ & \multicolumn{7}{c}{ Weeks after immunizing infection } \\
\hline I & 3 & $0,0,0^{*}$ & $0,0,0$ & 3 & 4 & 5 & 6 & 7 & 8 \\
\hline II & 5 & $0,0,0$ & $3,3,3$ & $3,3,2$ & $3,3,3$ & $3,3,3$ & $4,3,3$ & $3,2,2$ & $2,1,1$ \\
& & 0,0 & 2,2 & 2,2 & 2,2 & 3,3 & 3,2 & 2,1 & 1,1 \\
\hline
\end{tabular}

* Number of precipitin bands appeared in each sample. 


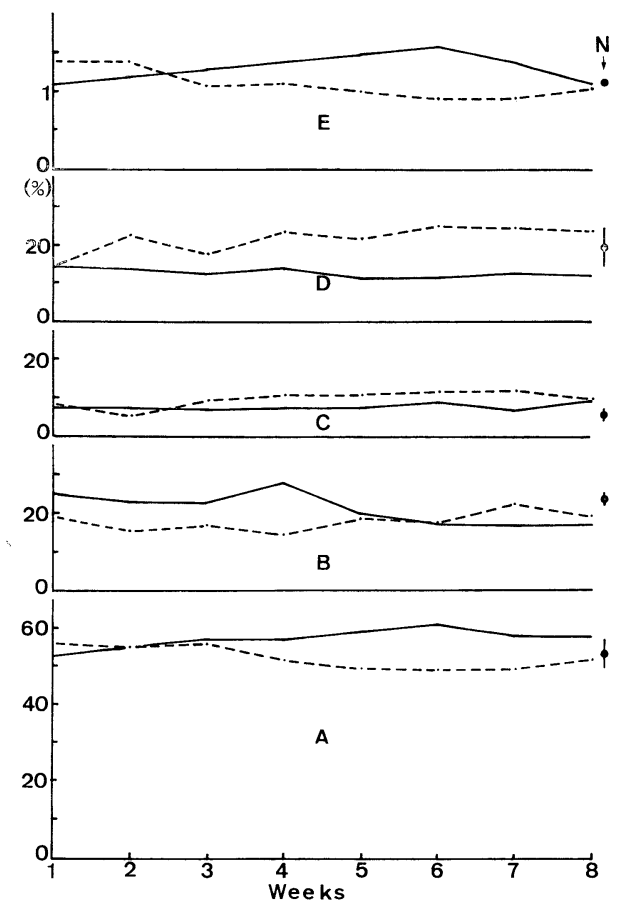

Figure 2 Weekly changes in each fraction of serum proteins in the samples from rats treated with (-) and without (---) immunosuppressive drugs; the rats in both groups immunized with the metacercariae per os and then challenged 6 weeks after the immunization. A: albumin, B: alphaglobulin, C: beta-globulin, D: gamma-globulin, E: A/G ratio, $\mathrm{N}$ : mean normal value of the non-infected and non-treated rats.

in the period the value in Group I was higher than those in Group II. The percentage value of beta-globulin in the two groups showed a similar trend indicating a slightly high rate of the value when compared to the normal value. In albumin fraction, on the other hand, a remarkable difference was found in the mean percentage between Groups I and II, during 4 to 8 weeks. A/G ratio in Group I had increased gradually up to 6 weeks, and then decreased, whereas it had decreased with the elapse of infection in Group II until necropsy.

\section{Discussion}

Kondo and Hashiguchi (1979) have observed, for the first time, on the influence of primary infection with Japanese species of Fasciola metacercariae to superinfection in rats. They demonstrated that the recovery rates of Japanese Fasciola from challenge infection were very low when compared to the natural-immunity control. The similar tendency, again, was also ascertained in the present study in rats, by 
carring out challenge during 6 to 11 weeks following immunization. During the period, the percentage immunity (reduction) had a considerable variation among the experimental groups designed. From 6 to 9 weeks after immunization, the percentage reduction was significantly higher in the challenged groups than the control, indicating the ranges from 58.3 to 80.6 per cent. It was noted, however, that the ability of rats to induce the protective immunity to the fluke had trended to reduce gradually in the animals 10 weeks $(25.0 \%$ immunity) after immunization; the immunity reduced to zero at 11 weeks.

In $F$. hepatica, this protective immunity following an oral infection has been amply documented as mentioned before. In most of these studies on the immunity to $F$. hepatica worm recoveries have been done after the flukes had matured. Hayes et al. $(1972,1973,1974 \mathrm{c})$, however, have performed a study on the ability of rats to resist a challenge infection with $F$. hepatica, recovering immature worms 3 to 4 weeks after challenge, and they have obtained a high rate of percentage reduction. This reduced worm burdens have also been recognizable during 24 to $48 \mathrm{hr}$ after challenge infection of rats with $F$. hepatica (Hayes and Mitrovic, 1977; Hayes, 1978). In the current study, therefore, the markedly reduced worm burdens from challenge would be present at the early phase of challenge infection in rats. However, exactly when and where protective immunity is expressed still remains undetermined, though the immunity to reinfection with $F$. hepatica in rats is expressed by $48 \mathrm{hr}$ after challenge (Hayes, 1978).

The protective immunity was examined in connection with the developmental ages of worms which were used in the immunization, and also with the liver migration of worms which might be related to induce the functional immunity in rats. Rajasekariah and Howell (1978) have examined the role of developmental stages of worms in the rat's resistance to challenge with $F$. hepatica. In their works the rats were sensitized by subcutaneous implantation of either metacercariae, 4 week-old juveniles, adult worms, or eggs of $F$. hepatica, and then challenged with the metacercariae 2 weeks later. All implanted stages, apart from adult worms, conferred a significant degree of protection on their recipient animals. With respect to the liver migration of worms, on the other hand, Lang et al. (1974) pointed out that the duration of liver migration by juveniles might be of greater importance in stimulating protective immunity in mice than was worm age. Thus, these observations suggest that there still remains undetermined factors in the mechanisms to induce protective immunity in the host animals against the genus Fasciola.

In order to study the immunological mechanisms which could underly the protective immunity, the immunizing infection was conducted by implanting the immature, 25 day-old, worms with and without diffusion chambers in the present experiment. The chamber allows for exchange of various materials between implanted parasites and their host (Hashiguchi et al., 1976). Besides, with the use of diffusion chambers the inability of parasites to infect the host would reduce or eliminate all of the pathology associated with the infection (Despommier and Wostmann, 1968). The present study revealed that the rats immunized by the worms in chambers showed a significant degree of protective immunity when compared to the naturalimmunity control or sham operation. The free worm implantation, however, stim- 
ulated a higher degree of the immunity than the worm implantation with chambers. These results suggest that the liver migration by the immature worms implanted may be responsible, at some extent, for stimulating the induction of protective immunity to the Japanese Fasciola in rats. It is of great interest that the enchambered worms are able to induce the protective immunity by releasing a variety of soluble antigen through the millipore chambers placed intraperitoneally in rats. Thus, the diffusion chamber technique permits the host to come into direct contact with the living parasites, thereby exposing it to a great variety of antigenic stimuli (Despommier and Wostmann, 1968).

In the rats sensitized by worm implantation with and without diffusion chambers, serological analysis demonstrated that there was a remarkable difference in the antigen-antibody systems between both implantations. During 1 to 2 weeks after worm implantation, the precipitin bands in agar diffusion plate were nearly equal in numbers in the two groups. After challenge, however, larger numbers of the bands were recognized in serum samples from rats sensitized with free worms than in those with enchambered ones. Considering the relation between the markedly reduced worm burdens and the appearance of many bands in free worm implantation (without chambers), Ouchterlony technique may be effective as an indicator to estimate the degree of protective immunity to Fasciola in host animals. Each fraction of serum proteins has not indicated a remarkable difference between the two groups.

There have been many attempts to reduce or eliminate the natural immunity of hosts against various parasites; in most of these cases workers have treated the host animals with immuno-suppressants and/or X-irradiation. Recently, Hashiguchi and Hirai (1977) have examined the influence of various immuno-suppressants on the establishment of the lung fluke, Paragonimus miyazakii in rats. They demonstrated that combined treatment with dexamethasone and prednisolone or with hydrocortisone and dexamethasone had suppressed the host's immune responses, while the use of dexamethasone or prednisolone alone had a relatively little influence on the immunity of hosts. In consideration of these results, the present work was attempted to determine if the combined treatment of rats with dexamethasone and prednisolone would have an effect on the protective immunity to the Japanese Fasciola or not. The treatment greatly suppressed the induction of protective immunity in rats sensitized by oral infection with the metacercariae, and then challenged 6 weeks later. Both treated and control rats harbored 3.3 and 3.2 worms in mean recovery, while non-treated but immunized and challenged rats showed a significantly fewer worm burden indicating 79.3 per cent worm reduction. Hayes and Mitrovic (1977) have administered dexamethasone into immunized rats with the metacercariae per os starting $24 \mathrm{hr}$ before challenge, and demonstrated that the drug used abrogated the protective effect of a previous infection. These facts indicate an important role of humoral immunity in the protective immunity to Fasciola in rats. No precipitin band in agar plate was observed in the rats given the immuno-suppressants throughout the experiment. The rats, on the other hand, theat were not given the drugs showed a considerable number of bands from 2 weeks after immunization. These results also suggest that antibody production was greatly suppressed in the animals given immunosuppressive drugs. Among fractions of serum proteins, gamma-globulin 
in the non-treated rats with the drugs was remarkably high in an average after 2 weeks, when compared to that in the treated animals; the latter marked a consistently lower rate than average normal value. Once again, these differences may be caused by the suppression of the host's immune responses.

In the present study, the protective immunity to the common liver fluke, Fasciola, in rats was examined using immunosuppressants or millipore diffusion chambers. The use of drugs and the chamber techniques would provide a good measure for the examination on the mechanisms which could be underlying the induction of protective immunity to the parasites in hosts. For the genus Fasciola, more detailed experimental systems such as various ages of worms and the timing and sites of immunization, are needed to clarify the mechnisms using these measures in relation to the host-parasite relationships.

\section{Acknowledgements}

The author express his deep gratitude to Professor Seiiti Inatomi, Department of Parasitology, Okayama University Medical School, for his kind guidance and valuable comments to the present work. Thanks are also due to Professor Noriji Suzuki, Department of Parasitology, Kochi Medical School, for his encouragement throughout this study.

\section{References}

1) Anderson, J. C., Hughes, D. L. and Harness, E. (1975): The immune response of rats to subcutaneous implantation with Fasciola hepatica. Brit. Vet. J., 131, 509-518

2) Armour, J. and Dargie, J. D. (1974): Immunity to Fasciola hepatica in the rat: Successful transfer of immunity by lymphoid cells and by serum. Exp. Parasitol., 35, 381-388

3) Corba, J., Armour, J., Roberts, R. J. and Urquhart, G. M. (1971): Transfer of immunity to Fasciola hepatica infection by lymphoid cells. Res. Vet. Sci., 12, 292-295

4) Dargie, J. D., Armour, J., Rushton, B. and Murray, M. (1974): Immune mechanisms and hepatic fibrosis in fascioliasis. In E. J. L. Soulsby (ed.), Parasitic Zoonosis. Academic Press Inc., New York, pp. 249-271

5) Despommier, D. D. and Wostmann, B. S. (1968): Diffusion chambers for inducing immunity to Trichinella spiralis in mice. Exp. Parasitol., 23, 228-233

6) Eriksen, L. and Flagstad, T. (1974): Fasciola hepatica: Influence of extra-hepatic adult flukes on infections and immunity in rats. Exp. Parasitol., 35, 411-417

7) Goose, J. and MacGregor, M. (1973): Naturally acquired immunity to Fasciola hepatica in the rat. Brit. Vet. J., 129, xlix

8) Hashiguchi, Y. and Hirai, H. (1977): Influence of immunosuppressants on the establishment of Paragonimus miyazakii in albino rats. J. Helminth., 51, 87-94

9) Hashiguchi, Y., Hirai, H., Okura, T. and Hiraoka, H. (1976): Effect of bithionol against Paragonimus ohirai and Paragonimus miyazakii in diffusion chambers implanted intraperitoneally or subcutaneously in rats. J. Parasitol., 62, 146-147

10) Hayes, T. J. (1978): Further evidence for the early expression of immunity to Fasciola hepatica in rats. J. Parasitol., 64, 374-376

11) Hayes, T. J. and Mitrovic, M. (1977): The early expression of protective immunity to Fasciola hepatica in rats. J. Parasitol., 63, 584-587 
12) Hayes, T. J., Bailer, J. and Mitrovic, M. (1972): Immunity in rats to superinfection with Fasciola hepatica. J. Parasitol., 58, 1103-1105

13) Hayes, T. J., Bailer, J. and Mitrovic, M. (1973): Immunity to Fasciola hepatica in rats: The effect of two different levels of primary exposure on superinfection. J. Parasitol., 59, 810-812

14) Hayes, T. J., Bailer, J. and Mitrovic, M. (1974a): Serum transfer of immunity to Fasciola hepatica in rats. J. Parasitol., 60, 722-723

15) Hayes, T. J., Bailer, J. and Mitrovic, M. (1974b): Studies on the serum transfer of immunity to Fasciola hepatica in the rat. J. Parasitol., 60, 930-934

16) Hayes, T. J., Bailer, J. and Mitrovic, M. (1974c): Acquired immunity and age resistance in rats with chronic fascioliasis. J. Parasitol., 60, 247-250

17) Howell, M. J., Sandeman, M. and Rajasekariah, G. R. (1977): In vivo and in vitro studies on the effects of immune rat serum on Fasciola hepatica. Int. J. Parasitol., 7, 367-371

18) Kimura, S. (1961): Experimental studies on Fascioliasis. III. Clinical and hematological observation on infected rabbits. Jap. J. Parasitol., 10, 336-341 (In Japanese with English summary).

19) Kondo, K. and Hashiguchi, Y. (1979): Influence of primary infection with Japanese Fasciola metacercariae to superinfection in rats. Res. Rep. Kochi Univ. (Nat. Sci.), 28, 73-80 (In Japanese with English abstracts)

20) Lang, B. Z. (1974): Host-parasite relationship of Fasciola hepatica in the white mouse. VI. Studies on the effects of immune and normal sera on the viability of young worms transferred to normal recipients. J. Parasitol., 60, 925-929

21) Miller, K. L. and Smithers, S. R. (1980): Schistosoma mansoni: The attrition of a challenge infection in mice immunized with highly irradiated live cercariae. Exp. Parasitol., 50, 212-221

22) Ono, Y. and Isoda, M. (1952): Studies on the Fascioliasis. III. Experiment on the artificial infection with metacercariae in rabbits. Jap. J. Vet. Sci., 14, 189-203 (In Japanese with English summary)

23) Rajasekariah, G. R. and Howell, M. J. (1977): The fate of Fasciola hepatica metacercariae following challenge infection of immune rats. J. Helminth., 51, 289-294

24) Rajasekariah, G. R. and Howell, M. J. (1977): Fasciola hepatica: Role of developmental stages in the rat's resistance to challenge. Exp. Parasitol., 44, 233-238

25) Rajasekariah, G. R. and Howell, M. J. (1979): Fasciola hepatic in rats: Transfer of immunity by serum and cells from infected to $F$. hepatica naive animals. J. Parasitol., 65, 481-487

26) Thorpe, E. and Broome, A. W. J. (1962): Immunity to Fasciola hepatica infection in albino rats vaccinated with irradiated metacercariae. Vet. Rec., 74, 755-756

27) Watanabe, S. (1965): A revision of genus Fasciola in Japan, with particular reference to $F$. hepatica and F. gigantica (ed. Morishita, K., Komiya, Y. and Matsubayashi, H.) Progress of Medical Parasitology in Japan, 2, 359-381. Meguro Parasitological Museum, Tokyo. 
免疫抑制剂および Diffusion Chamber 移植法によるラットの日本産 カンテツに対する防御免疫効果の検討

橋口義 久

カンテッ Fasciola Repatica については, 初回の感染によって, 宿主動物の再感染に対する防御免 疫が強く発現されることが知られている。しかし，分類学的位置づけが未だ不明確な日本産カンテッ に対する宿主の防御免疫についての研究は極めて少ない。今回は，日本産カンテッによる初感染後 6〜11週目にラットを再感染させたところ，6〜9週目の再感染群では，対照群 (Challenge control) に比へて，有意の虫体排除が認められた。しかし，乙の防御免疫能は初感染から 10 週以降になると次 第に低下し, 11 週後では対照群との間に差異を示さなかった。この防御免度効果を調べるため, 幼若 虫体を Diffusion chamber に人れ, ラット腹腔内移植による感作を行い, 移植 3 週後に再感染を試み たところ, 防御効果が観察された。しかし, 虫体のみの移植群に比べる, その効果は低い傾向を示 した。このととは, 虫体のみ移植群において, 移植虫のラット肝臓内穿人による刺激が，何らかの形 で強い防御免疫の発現に関与しているととを示唆するすので興味深い。また，てれらのラット血清を Ouchterlong 法で調べたところ, 虫体のみ移植群では Chamber 移植虫群より, 多くの沈降線が出現 し，抗体産生の面であ両群間に違いがみられた。一方，血清蛋白画像は両者間で大差なく，いずれむ 虫体移植，再感染を通して，かをりの変動を示した。次に，ラットの再感染防御免疫に対する免疫抑 制剂 (Dexamethazdne と Predonisolone の併用) の影響を調べた結果, 免疫抑制群では, 対照群と 同様の虫体回収を示した。したがって，てれらの抑制剤は今回の防御免の発現を著しく抑制するてと が明らかになった。また免疫抑制群では, Ouchterlongによる沈降線の出現は皆無であったのに対し， 非免疫抑制群では, 初感染から 2 週目以降に多数の沈降線が出現した。免疫抑制群の蛋白分画では r-globulin 值が著しく低下し, 非抑制群との間に大差を示した。以上の結果は，ラットのカンテッ再 感染防御機構を調へる上で，一つの手がかりを与えるものといえよう。

高知医科大学環境保健医学講座寄生虫学教室 